\title{
Customer Retention Activities Using IoT Data:
}

The Case of "@Remote” by Ricoh

\section{IOT データを利用した顧客維持活動}

ーリコー@Remote の事例

\section{Hisashi Kawamata ${ }^{* 1}$, Takeshi Moriguchi ${ }^{{ }^{2}}$}

\section{早稲田大学大学院 商学研究科 博士後期課程}

河股 久司
早稲田大学 商学学術院 教授

守口 剛

${ }^{*}$ G Graduate School of Commerce, Waseda University, h-wasesyou@ruri.waseda.jp

${ }^{* 2}$ Faculty of Commerce, Waseda University, moriguchi@waseda.jp

\section{@Remote}

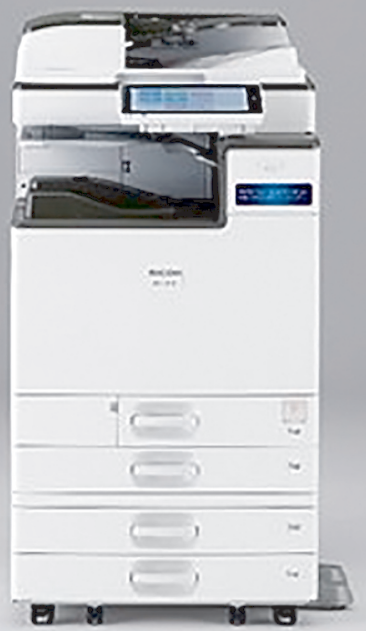

Abstract : In recent years, many companies have used data-based marketing to understand customer insight. In this article, we focused on Ricoh, which uses customers' data to conduct efficient customer retention. We revealed that Ricoh has been carrying out efficient customer maintenance activities using a data collection system called "@Remote" related to the use of MFPs (Multifunction peripherals). In addition, through interview surveys, we confirmed that the knowledge of sales representatives was aggregated and utilized together with the data. This aggregation contributes to the success of customer retention activities. This article indicates the importance of the role of sales representatives that 
Marketing Case マーケティングケースー シリーズ 137

serve as a bridge between data and customers when companies conduct data-based marketing.

Keyword : IoT, Customer orientation, Salesperson

要約 : 近年, デー夕を活用したマーケティング戦略を行う企業は増加の一途をたどっている。顧客の理解のために, 顧客の製品 利用に関するデー夕を活用した事例も存在する。本稿では, 顧客の製品利用デー夕を活用して効率的な顧客維持活動を行ってい るリコーに焦点を当てる。リコーは,「@Remote」と呼ばれる複合機の利用に関するデ一タ収集システムを活用し, 効率的な顧 客維持活動を行っている。インタビュー調査を通じて, 複合機利用データを活用した既存顧客維持活動の成功の背景に, それま で属人的であった営業担当者のノウハウや知識が活かされていることなどが明らかとなった。このことは, データの利活用に際

し，データと顧客をつなぐ架け橋となる営業担当者の役割の重要性を示唆している。

キーワード : IoT (モノのインターネット), 顧客志向, セールスパーソン

\section{I.はじめに}

企業は, 既存顧客の維持と新規顧客の獲得という 2 つ の活動を通して自社の売り上げや市場シェアの拡大を図 る。しかし，限られた人員と時間の中で既存顧客の維持 と新規顧客の獲得を同時に行おうとすると，いずれかに 偏ってしまう場合が多いと考えられる。顧客維持のため に既存顧客の元を訪問し続ければ，新規顧客の開拓を行 う時間がそしくなる。一方で，新規顧客の開拓ばかりに 目を向けていると, 既存顧客への対応がおろそかになり, 結果として既存顧客が離れていくだろう。このようなジ レンマを抱える企業は少なくない。特に, 市場が成熟し, 多くの顧客に製品がいきわたってしまうと，市場シェア の奪い合いが発生する。企業の収益を上げていくために は，このジレンマを克服し，既存顧客を離反させずに新 規顧客を開拓する必要があるだろう。

このようなジレンマは, 特に BtoB 市場において顕著 にみられる。なかでも OA 機器に関しては, 各企業・事 業所ごとに PC や複合機は十分に取り揃えられており, 市場が成熟している。そのため, 既に OA 機器を導入し ている企業・事業所をめぐって, 競合企業同士で顧客を 奪い合うという状況が発生しやすい。OA 機器メーカー は, 自社の収益を確保するために, 既存顧客の維持と新 規顧客の獲得の双方に注力する必要がある。

しかし，先に述べた通り限られた人員と時間の中で, 既存顧客を維持しながら新規顧客を開拓することは難し
く,いずれか一方の戦略にのみ偏ってしまうケースが多 い。特に, 新規顧客の開拓は, 既存顧客の維持よりも多 くのコストが発生するものの, 市場シェアを拡大するこ とができるため, 既存顧客の維持よりも重点が置かれる ことがある。一方で，新規顧客の開拓に比重をかけすぎ ると, 既存顧客へのアプローチが少なくなってしまう。 とはいえ, 現在の市場シェアを維持するためには, 既存 顧客をいかに維持し，ブランドスイッチ率を下げること も極めて重要である。そのため, 新規顧客獲得活動を重 視する企業では，限られた時間の中で既存顧客へのアプ ローチをいかに効率的かつ効果的に行うことができるか が重要な課題となる。

そこで, 本稿では, 新規顧客獲得活動を行う傍らで, 既存顧客への適切な訪問タイミングを顧客のデータから 予測し, 顧客維持率を向上させた例を検討し, その成功 要因を探る。具体的には, リコーの複合機リモート管理 サービス「@Remote」を活用した効率的な顧客維持活動 について検討する。@Remote は, 顧客との契約に基づ き, 顧客の複合機利用状況や複合機の状態を遠隔で情報 取得ができるシステムである。このシステムは, 複合機 というモノをインターネットに接続し, 複合機を管理す るだけではなく，利用状況などに関する情報収集を行う IoT $^{1)}$ (Internet of Things）技術によるデータ活用といえ よう。本稿では, IoT 技術によって取得されるデー夕を 生かし，既存顧客の維持活動を行った事例を取り扱う。

なお，本稿の構成は以下のとおりである。続く第 2 章 で, リコーの企業紹介とリコーの主力製品である複写機 
や複合機の系譜を紹介する。第 3 章では, BtoB を対象と した複合機のビジネスモデルについて概略を説明する。 第 4 章では, 2008 年に起きたリーマンショックがリコー にもたらした課題について述べる。第 5 章では，前章で 挙げた課題を克服すべくリコーが取り組んだ IoT データ によるマーケティング活用事例を紹介し，第 6 章でその 効果を述べる。第 7 章で, 本事例の成功要因を考察し, 最後の第 8 章でまとめを行う。

\section{II. オフィス事業の効率化に特化したリコー}

リコーの来歴は 1936 年にまでさかのぼる。理化学研 究所で発明された製品の工業化を目的に発足した理化学 興業から独立した理研感光紙株式会社がリコーのはじま りである。1938 年に理研感光紙株式会社は理研光学工業 株式会社に社名を改め, 1955 年に国内初のジアゾ複写 機2)「リコピー101」を発売した。事務作業の合理化を目 的にリコピー 101 は開発されたこともあり，以降オフィ スに打ける事務作業の効率化を企業の目的に据え，複写 機の開発や製造を手がけるようになった。その後，1963 年に理研化学工業から現社名であるリコーに社名変更を 行った。1977 年には，OA（オフイス・オートメーショ ン）を業界で初めて提唱し，OA 機器の中で重要な位置 を占めるオフィス用コピー機 (複合機) を精力的に開発・ 発売した。なかでも，1982 年に発売を開始したリコピー FT シリーズは，拡大・縮小機能を備えた普通紙コピー 機であり，発売からわずか 10 か月で 10 万台を売り上げ た。これは, 1982 年の静電式複写機の販売台数が 137 万 台程度 ${ }^{3)}$ であることからすると，1 種類の複写機で年間 の複合機販売台数の $10 \%$ 近くを販売したことになる。そ の後も，リコーの複合機の代表格となる IMAGIO シリー ズを開発・販売し，数多くの複合機を市場に導入した。 2001 年には複合機を使用しない時間の待機電力を低電力 で保ち，使用時には即座に使用できるという QSU（Quick Start Up）技術を用いた「imagio Neo 350 シリーズ」が, $\mathrm{OA}$ 業界で初めて省工六大賞「経済産業大臣賞」を受賞 するなど，その高い技術力を発揮した製品が製造・開発 されている。その後，現在に至るまで $\mathrm{OA}$ 機器の開発・
製造・販売を事業の中心に置いている。

2018 年 3 月期現在,リコーの売上高（連結ベース） は，2 兆円を超えており，グループ企業数も 200 を超え る。売上を分野別にみると, オフイス向け複合機や複写 機，プリンターの生産・販売・リースサービス・リサイ クルなどを行うオフィスプリンティング事業が $55.4 \%$, サーバーやネットワーク関連機器の販売・サービス, サ ポートなどを行うオフィスサービス事業が $21.7 \%$ となっ ており，この 2 つの事業でリコー全体の売り上げの $75 \%$ を超えている4)。リコーは OA 機器以外にも, 家庭用デ ジタルカメラなどの製造・販売を行っているが，先に述 ベた通り，オフィスプリンティング事業とオフィスサー ビス事業の 2 つの事業が，売り上げ全体の $75 \%$ 以上を占 めており，リコーは，オフィス向け，つまり BtoB 向け の製品やサービスの販売を企業の軸となっている。

\section{III. 複合機のビジネスモデル}

一般に, 企業が複合機を導入する際, 顧客と複合機メー カーおよび販売会社は 2 つの契約を締結する。1つ目は 販売契約, 2 つ目は保守契約である。始めに販売契約で あるが，次にあげる 3 つの方法のいずれかを採用し複合 機を導入する。1つ目は，複合機メーカーから複合機を 直接購入するという方法，2つ目は企業がリース会社と リース契約を結び，長期的に複合機をリースするという 方法，そして $3 つ$ 目はレンタル契約である。レンタル契 約はリース契約と基本的な考え方は似ているが，契約期 間が短く，数か月から最長で 3 年程度である。レンタル 契約は主として, 建設工事現場事務所や選挙事務所, 国 際会議などといった，短期間で複合機が必要な場合に締 結される契約である。上記 3 つの方法があるが，多くの 企業はリース会社とリース契約を行い, 複合機を導入す る。ここでは, 最も利用が多いリース契約に基づく複合 機利用について説明する。

リース契約によって複合機を利用している企業は,リー ス料をリース会社に支払う。それは, 企業が複合機のリー 久契約を結ぶ際，リース会社が複合機を所有しているた めである。そもそも，複合機はいくつかの企業を経て， 
Marketing Case マーケティングケース — シリーズ 137

顧客企業のもとにリースされる。まず，複合機の生産を 行っている複合機メーカーは, 複合機本体を販売会社に 販売する。次に，販売会社は複合機をリース会社に販売 する。この時, 複合機の所有権はリース会社が保有して いる。そして，顧客企業はリース会社と契約を結び，リー ス会社が保有している複合機を借りるのである。そして, その賃借料としてリース会社に月額のリース利用料を支 払う。

このようなリース契約は顧客企業にとっても，複合機 メーカーにとってもメリットがある。顧客企業にとって は，複合機を直接的に所有するわけではないので，初期 投資をかけることなくサービスを利用できる点がメリッ トとして挙げられる。特に複合機などの高額な製品の場 合は，初期投資を必要としないことは大きな利点になる と考えられる。また, 複合機などの高額な機器を購入し た場合, 企業の固定資産として計上される。そのため, 固定資産税が発生したり, 耐用年数に応じて減価償却を 行う必要がある。しかし, リース契約の場合は, リース 会社が複合機を保有していることになるため，企業側が 固定資産税の支払いや減価償却の計上を行う必要がなく なる。また，複合機メーカー側にとっても，顧客企業が サービスを利用するためのハードルが低くなることは, 顧客の新規獲得や機種変更時の継続利用を促す効果が ある。

次に保守契約であるが，大きく分けて 2 つの契約があ る。1つ目はスポット方式と呼ばれ, 点検・修理・部品 交換など顧客の要望に応じて毎回有償にて実施する契約 である。2つ目は顧客企業が複合機を安定した状態で使 用できるように，保守要員が複合機設置先である顧客企
業へ訪問し，定期保守（点検・調整）を実施する対価と して印刷枚数に応じた料金を課金する契約である。この 契約は印刷頻度によってさらに契約形態が細分化され， 印刷頻度が高い場合にはカウンター方式, 印刷頻度が低 い場合にはキット方式（トナー方式）と呼ばれる。リコー の複合機を利用している顧客の大多数がカウンター方式 の契約を選択している（図表1）。

カウンター方式で契約した場合における保守料金は 2 段階構造となっている。1段階目は月額の基本料金であ る。これは印刷の有無にかかわらず課金されるものであ る。そして, 2 段階目は従量課金の部分である。複合機 メーカーは, 各企業に対して印刷枚数に応じた料金を請 求しており, この従量課金部分が, 複合機メーカーの利 益の大きな部分を占める。

複合機ビジネスは，保守契約という形式をとることで, 複合機そのものを売るのではなく，印刷機能などの便益 を安定的に稼働させるというサービスを消費者に提供し ている。このような製品のサービス化 (Product as a Service $[\mathrm{PaaS}] ）$ の事例は数多くあるが，その 1 つとして 複合機ビジネスも挙げられる。

複合機メーカーと企業の間のリースおよび保守契約の 関係をまとめると図表 2 のようになる。複合機メーカー は，複合機を販売会社へ販売し，販売会社はその代金を メーカーに支払う。販売会社がさらにリース会社へ販売 する。そして, リース会社は顧客企業にリースを行い, 月額の利用料を顧客企業はリース会社へ支払う。一方で, 印刷料金は, 複合機メーカーが直接カウンター料金を顧 客企業に請求し, 顧客企業は複合機メーカーに対して支 払いを行う。

\begin{tabular}{|c|c|c|}
\hline 販売契約 & 所有権 & 所有期間 \\
\hline 購入 & 顧客企業 & 長 \\
\hline レンタル契約 & レンタル会社 & 短 \\
\hline リース契約 & リース会社 & 長 \\
\hline
\end{tabular}

\begin{tabular}{|c|c|c|}
\hline 保守契約 & メンテナンス費 & トナー代 \\
\hline スポット方式 & 有償 & 有償 \\
\hline キット (トナー) 方式 & $\begin{array}{c}\text { トナー代金に } \\
\text { 含まれる }\end{array}$ & 有償 \\
\hline カウンター方式 & 保守料に含まれる & $\begin{array}{l}\text { 保守料に } \\
\text { 含まれる }\end{array}$ \\
\hline
\end{tabular}

筆者作成 


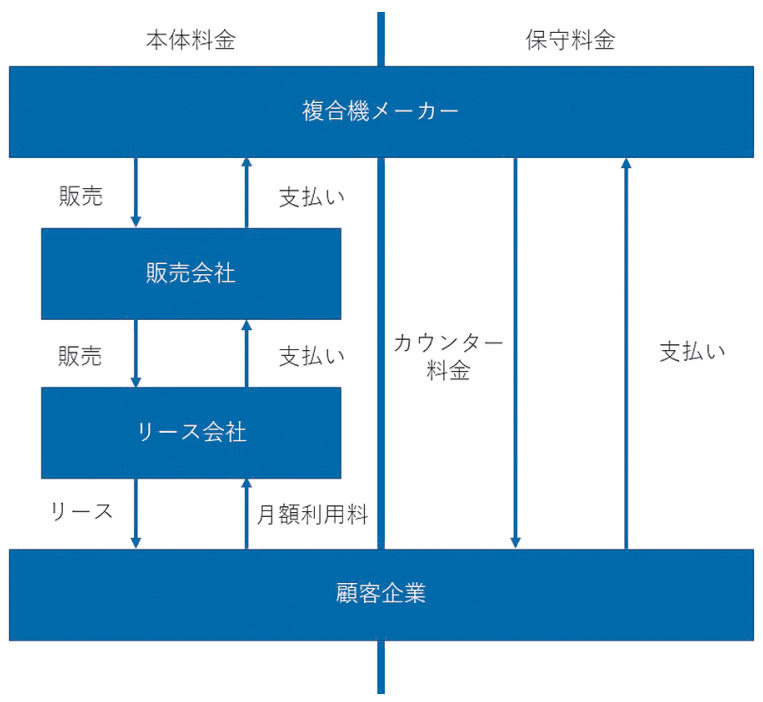

(筆者作成)

複合機の継続利用は，複合機メーカーにとって大きな 収益を生み出す要因となる。継続的な利用によって, 恒 常的に保守契約による保守料金を収入として得られるか らである。保守料金は，その大部分が印刷枚数に応じた 従量課金であるため，印刷枚数が増加するほどに複合機 メーカーの収入が増えることになる。つまり，いかに印 刷枚数を増やすかが，複合機メーカーの収益に直接影響 を及ぼすといえる。印刷枚数を増やすためには，個々の 複合機当たりの印刷枚数を増やすか，市場内における自 社製複合機の台数を増加させることが考えられる。前者 は複合機メーカーの取り組みで増加させることは難しい。 一方で，市場内における自社製の複合機の台数は，複合 機メーカーの営業戦略によって増やすことができる。つ まり，複合機メーカーにとっては，自社製の複合機を多 くの企業で導入・利用していることが重要であり，それ が複合機メーカーの売上や収益を伸ばすことにつながる。 そのため，市場における自社製複合機の台数を増大させ るためには，既存顧客を維持するだけではなく，新規顧 客を取り入れる必要があると考えられる。

\section{IV. 国内営業部門が抱えていた問題}

第 2 章で述べたように，オフィスプリンティングなど の BtoB 事業を企業の軸としているリコーにとって, 2008 年のリーマンショックの影響は大きかった。顧客企業が 倒産や事業の縮小などに見舞われ, その結果, 複合機の 需要が落ち込むようになった。日本国内における複合機・ 複写機の年間出荷台数を見ると, 2008 年が 62.5 万台, 2009 年が 52.2 万台, 2010 年が 55.2 万台とリーマン ショックを境に大きく減少していた（図表 3 : 棒グラ フ）5)。出荷台数が減少することは, 日本国内で稼働し ている複合機の台数が少なくなることを意味する。また， 複合機は通常 5 年程度で新しい複合機と交換されるた め, 今後 5 年間は, 日本国内に存在する複合機の台数が 少なくなることが想定されていた。複合機の出荷台数が 少なくなれば, 当然ながら, 複合機の稼働台数も少なく なり, 印刷枚数の総数も減る。印刷枚数が減るというこ とは，印刷料金による収益が減少することを意味する。 つまり, リーマンショックの影響は, BtoB を対象とした 事業活動を主軸におくリコーにとっては, 憂慮すべき問 題であった。 
Marketing Case マーケティングケース — シリーズ 137

リコーは, リーマンショックによって市場規模が小さ くなると，売り上げの確保のため，積極的に新規顧客獲 得活動を行うようになった。新規顧客獲得は, 既存顧客 の維持活動よりも受注成約までにかかる時間が長くなる 上に，成約率も低い。既にリコーとの取引関係が成立し ている既存顧客を維持する活動に比べて非常に効率の悪 い方法である。しかし，リコーは多くの新規顧客を取り 入れることで縮小する市場規模の中で収益を保とうとし
ていた。とはいえ, 営業担当者が 1 日で回れる顧客先数 は限られており，新規顧客先へ数多く訪問することで, いままで訪問することができた既存顧客企業の元へ頻繁 に訪問することが難しくなりつつあった。それでも， 2011 年までは新規顧客と既存顧客への活動バランスを取 りながら販売シェアを維持していたが，2012 年には減少 へ転じた。

このシェアの低下を危惧したリコーは，ょり高い新規

\section{A3MFP Market share (JPN)}

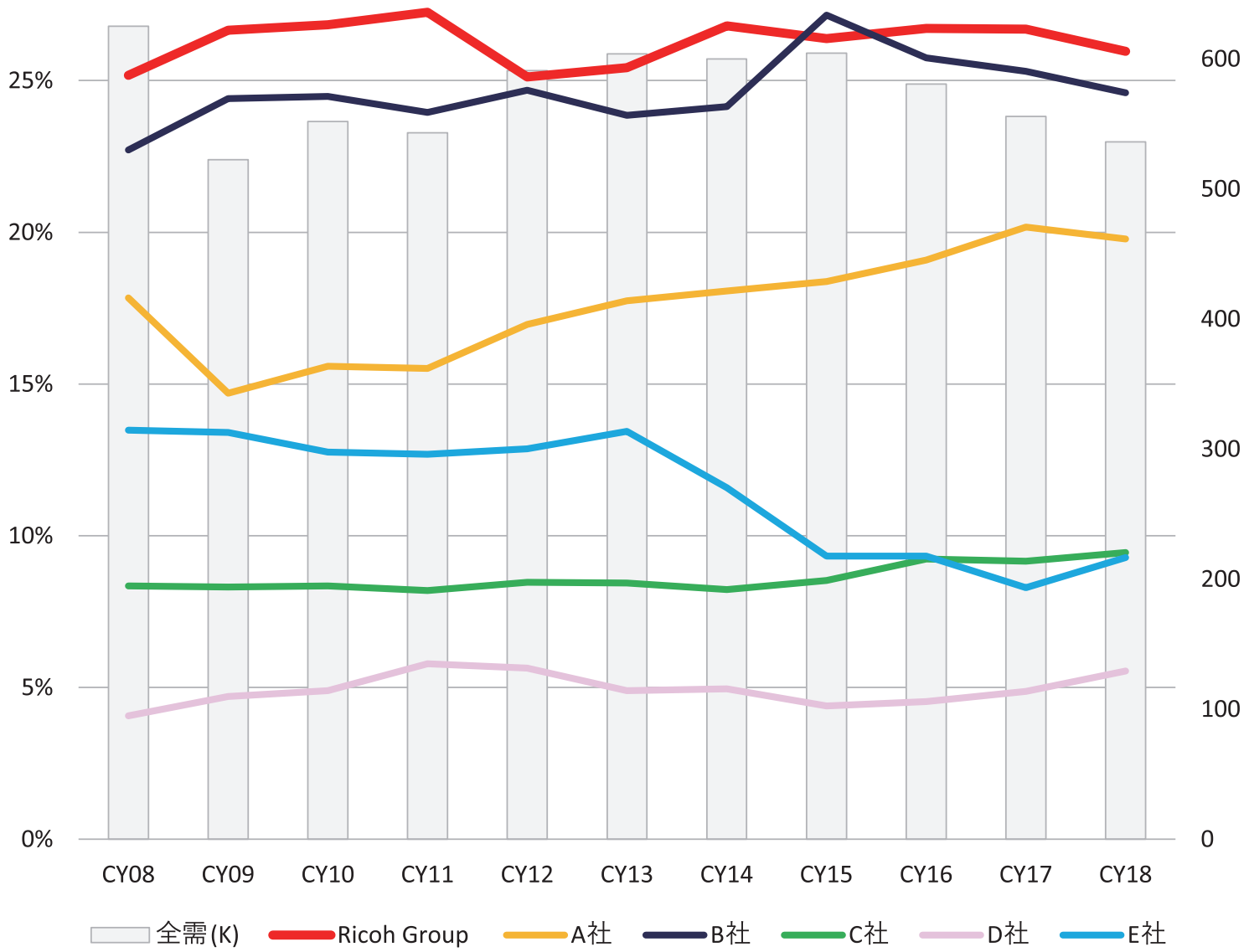

Source: IDC's Worldwide Quarterly Hardcopy Peripherals Tracker 2019Q2

- Laser MFP/SFDC, A3, Speed Range A4: 91+ppm excluded

- Copier Shares by Company 
顧客の獲得を目標にしつつ，既存顧客の維持も同時に行 う必要性を感じるようになった。しかし，冒頭で述べた ように，新規顧客の獲得と既存顧客の維持はいずれかに 偏りがちになってしまう。とはいえ，販売シェアの低下 を食い止めるためには，新規顧客の獲得を行いながら今 いる既存顧客を確実に維持する必要があり,これがリコー にとって解決すべき契緊の課題となっていた。

\section{IoT データのマーケティング活用}

前章で述べた通り，2008 年秋に発生したリーマン ショックによって，顧客企業が倒産したり，事業規模縮 小に見舞われた。事業規模が小さくなることで複合機の 需要が減り，複合機市場が縮小していた。そこでリコー は，縮小する市場の中で売り上げを確保すべく，今まで 以上に新規顧客獲得活動が重視されるようになり，頻繁 に既存顧客の元を訪問することが難しくなっていた。新 規顧客獲得活動を行いながらも同時に既存顧客の元も訪 問しなければならないという状況にあったリコーは，効 率よく既存顧客の元を訪れることができるような仕組み を考案する必要があった。

このような中で，効率的な既存顧客企業への訪問を実 現化するために考えられていたのが，複合機利用に関す るデー夕の活用である。もともとリコーは，顧客の複合 機利用に関するデー夕を大量に有していた。それらは， @Remote と呼ばれる複合機のリモート管理サービスに よって取得されたデータであり，リコーは，2004 年から ブロードバンド回線を用い, 顧客先にある複合機からデー 夕を取得していた ${ }^{6)}$ 。2013 年頃には，@Remoteは日本 国内で稼働している複合機の大多数に搭載されており， 百万台近い複合機からデータが集められていた。また， 取得できるデー夕も複合機の稼働状沉から，紙詰まりの 頻度や場所，発生時間，および各種センサー値に至るま で数千種類にわたり, 取得頻度も 1 日に 1 回という高頻 度でデー夕が取得されたいた。これらのデー夕は，複合 機という「モノ」をインターネット回線につなぎ，情報 を取得できるIoT の仕組みを活用し収集されたデータで ある。IoT の仕組みを活用した@Remote から取得される
データは非常に有益なデータであったが，2013 年 3 月ま では部門単位で利用されており, トナーの自動配送通知 や, 複合機の保守点検といった, 複合機の品質や利用満 足向上を目的にデー夕が活用されていた。

2013 年 4 月より, @Remoteによって取得されたデー 夕を全社的に活用する方針が決まり,データサイエンティ ストの体制を整えた。これを機に，@Remoteによって 収集されたデー夕を、マーケティング活動のために利用 する機運が高まった。そして，この機運の高まりに合わ せ，マーケティングアナリティクスがテーマ化され様々 な部門から人材が集められた。彼らは, 早速にIoT の仕 組みである@Remote から得られるデー夕を顧客維持活 動のために活用し始めた。そして，顧客のインサイトを @Remote のデー夕を通して把握を試みようとしたので ある。

IoT デー夕を活用した事例の 1 つ目に, 機械学習を利 用した複合機の買い替え予測モデルの開発が挙げられ る。買い替え予測は，いくつかの変数から検討すること ができるという考えがマーケティングアナリティクスチー ムにはあった。それらの変数として，複合機導入からの 経過期間のみならず，顧客企業からの過去の発注履歴や 案件情報などから取得できる設備への投資意欲，過去の 購買履歴やカスタマーセンターとの通話記録などマーケ ティング活動から得られたデータなどが検討されていた。 それらの変数に加え，@Remote から取得できるデー夕 の中から, 印刷枚数や印刷方法など機器の利用状況に関 するデータや，紙詰まりやパーツの污損などの故障に関 するデー夕などを予測モデルの一部に組み込んだので ある。

ある複合機の印刷枚数が前年と比べ格段に増えている 場合, その複合機を利用している企業の印刷需要が高まっ ていると考えられる。その場合は，印刷スピードが速い 複合機へ買い替えを行う方が顧客企業にとって望ましい だろう。また，スキャン機能を多く利用している企業で あれば，文書のクラウド化ができるような複合機を提案 すれば，顧客企業はその複合機に興味を持つかもしれな い。また，故障についても，故障が頻発しているようで あれば，新たな複合機へと買い替えようという思いは高 まるであろう。このように，@Remote から検知される 
Marketing Case マーケティングケース — シリーズ 137

複合機利用に関するいくつかの変数を用い, 複合機の買 い替えタイミングを予測するモデル（図表 4）を作成し たのである。

また，買い替えタイミングが近づいている顧客企業が ある場合，その顧客企業を受け持つ営業担当者と保守要 員に，買い替えタイミングが近づいていることをメール で伝える仕組みを併せて作成した。さらに，電話で企業 に営業活動を行う部署にも同一の内容が参照できるよう にした。この仕組みによって営業担当者が，自身が担当 する顧客企業が買い替えタイミングにあることを容易に 把握できるようになったのである。

2 つ目の IoT データの活用として, 顧客企業により良 い利用方法を提案できる顧客向け提案書と，営業担当者 が顧客の状況を確認できる資料（図表 5）を自動生成す る仕組みを開発した。この提案書と確認資料は, 顧客企 業ごとにカスタマイズされた内容が記されており，顧客 企業の複合機使用状況や印刷枚数の推移, 顧客企業に とって最も利便性が高い複合機の案内などが提案書に記 載されるようにしたのである。これらの情報をもとに， 営業担当者は企業に提案を行い, 買い替え需要を創出す ることができるようになったのである。

マーケティングアナリティクスチームは，複合機の利
用状況に関するデータを収集する@Remoteを活用し， 買い替え需要を予測, 営業担当者へ買い替え需要のある 顧客企業を通知，そして営業担当者による買い替えの具 体的な提案，という一連の流れを作り上げた。この IoT の仕組みを活用した一連の流れを，リコー社内では「AI スマートッール」と呼ぶようになった。AI スマートッー ルによって，いままで見えなかった顧客の買い替えの需 要を営業担当者に自動で伝え, 効果的に既存顧客の元を 訪問できるようになったのである。

$\mathrm{AI}$ スマートツールの開発は, マーケティングアナリ ティクスチームによって行われているが，この開発に当 たっては他部門の意見を多分に取り入れているという。 中でも, 営業部門, 特に営業担当者の意見は, 予測モデ ルに採用する変数や提案書に記載する内容に強く反映さ れている。それは，顧客を理解するためには，デー夕だ けではなく，顧客の声を直接聞いている営業担当者の意 見も重要であるという理解が, マーケティングアナリティ クスチームに存在するからであった。この意見の反映こ そがIoT データを活用したマーケティング戦略において 大きな意味を持つと考えられるが，この点についてはの ちに詳しく考察する。

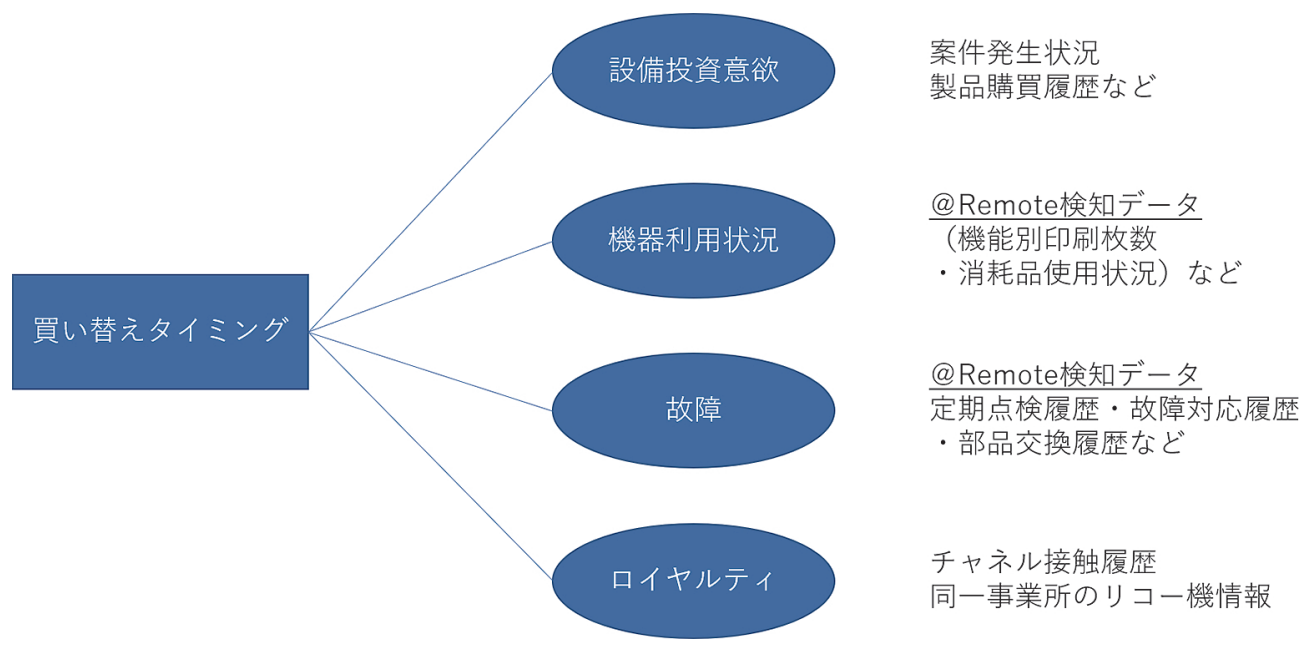

出所：リコー資料より筆者修正 


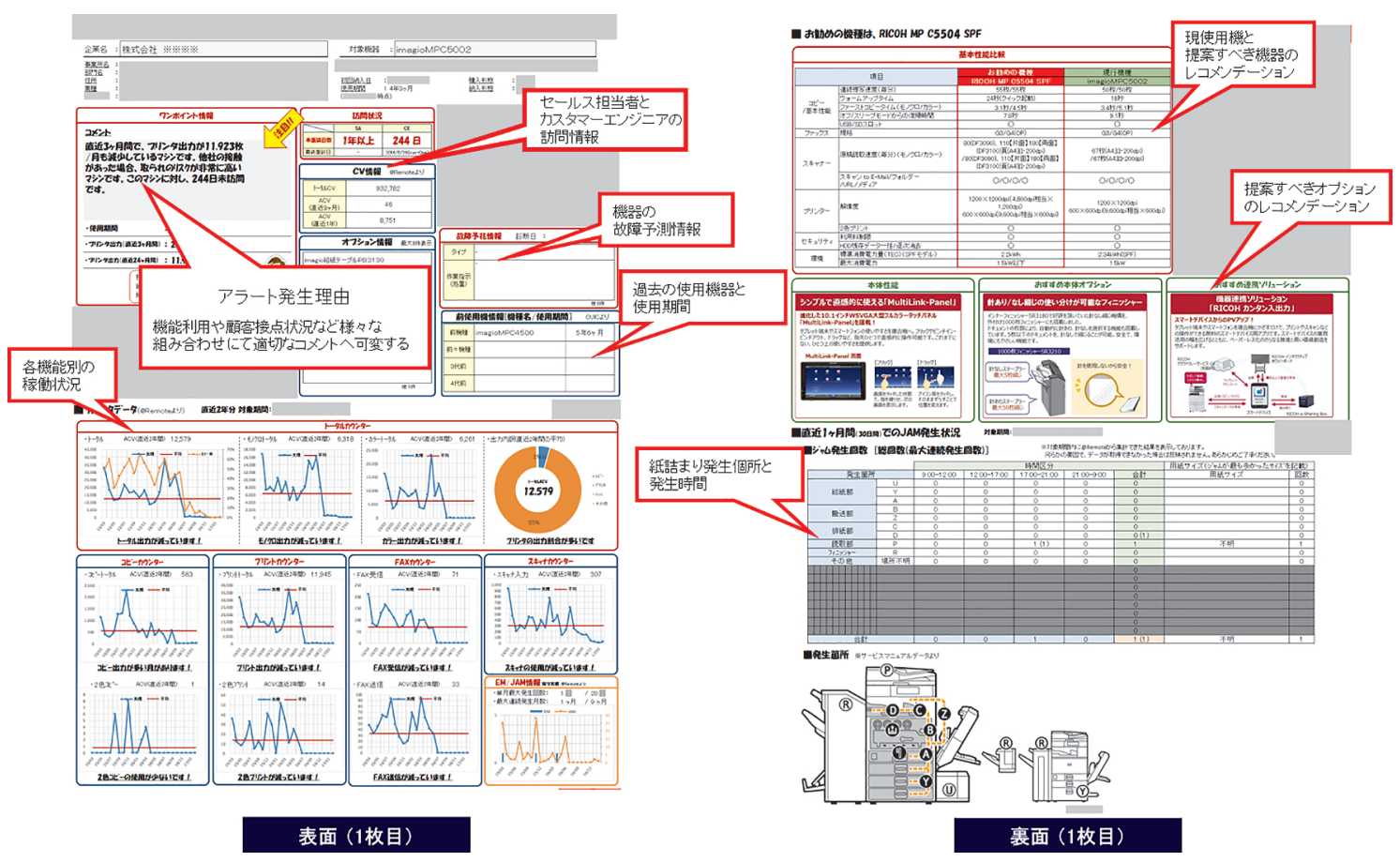

出所：リコー提供

\section{AI スマートツールがもたらした効果}

AI スマートツールを用いた既存顧客へのアプローチが もたらした効果は著しい。ある国内営業所では買い替え 予測モデルを用い，買い替えの可能性が高い顧客に対し て買い替えを進めた場合，受注成約率が 3 倍以上になっ たという。適切なタイミングで買い替えを勧めることで, 成約率が高まった例といえる。さらに，適切なタイミン グで顧客訪問ができたことによって，既存顧客のリコー 製複合機の継続利用率が前年同期比で 10 ポイント以上 も上昇した営業所もあったという。

また, @Remoteによるデー夕活用は，ほかにもメリッ トを及ほしている。営業担当者は, 提案書を通じて顧客 企業の複合機使用状況を把握できるようになった。その ため, 顧客の元を訪ねる前に顧客の使用状況を把握し, 訪問時に，利便性を高める複合機の利用方法を提案でき るようになったという。2013 年当時マーケティングアナ
リティクスチームに所属していた福住氏は「利便性を高 める使用方法を顧客企業へ伝えることで, 顧客がリコー の複合機を長く使おうと思ってくれることを最も重要な 要件であると考えている。他社製品へスイッチされると， リコーの収益は 0 になってしまうが，長期的にリコーの 複合機を使ってもらえる関係を築くことで，長期的な収 益を確保できる」としている。

さらに, 適切な買い替え予測に基づいて買い替えを提 案し, 実際に買い替えが行われることは, 既存顧客の満 足度を高める要因にもなっている。複合機を長期間使い 続けていると, 消耗品の摩耗が激しくなり, 紙詰まりや 故障の機会が増える。しかし, 適切なタイミングに買い 替えを案内し，新型の複合機を導入することによって， 故障の機会の減少につながる。故障の機会が減少するこ とで，顧客企業は快適に複合機を使用し続けることがで き，顧客満足がより高まったという。

@Remote を活用した適切な買い替え予測モデルを利 用することで, 既存顧客へ適時適切なアプローチが可能 
Marketing Case マーケティングケースー シリーズ 137

となった。また，それ以外の時間を使い，新規顧客の もとを訪ねることができるようになった。その結果, @Remote によって取得できるデータをマーケティング 活用し始めた 2013 年以降, 徐々に出荷台数シェアを回 復させ， 2014 年以降は，2011 年のシェア率とほぼ同水 準の 26〜27\%を維持している（図表 3 : 折れ線グラフ）。

\section{VII. 成功要因の考察}

ここでは，@Remoteを活用した既存顧客維持活動の 成功要因を考察する。成功要因の 1 つめは, 複合機の使 用状況に関するデータをマーケティング戦略に生かした ことであると考えられる。これは, IoTデータをマーケ ティング戦略に活用したと換言することができるが, IoT の概念がさほど普及していなかった 2013 年から具体的 な活動を取り組んでいたところにその成功要因があった と考えられる。IoTが全盛となった今では，さまざまな データを活用しそこから顧客のインサイトを発掘するこ との重要性はすでに知られているが, IoT の活用が全盛 期を迎える前から, IoTデータを用い, 顧客のインサイ トの把握に努めた点が，1つの成功要因だと考えられる。 2013 年当時, マーケティングアナリティクスチームの リーダーを担当していた小野氏も,「@Remote から取得 されたデー夕を活用することで，今まで以上にお客様を 深く理解できるようになった」と述べている。また，そ れに続けて「お客様を深く理解できるようになったこと で，新たな提案ができるようになった」と言う。顧客の 目線に立ってものを考え, 顧客に価值のある提案を行お うとする顧客志向の重要性は, マーケティングの分野で も古くから取り上げられており（Kuriki, 2012），企業に おける顧客志向の高まりとビッグデータ利用の関係性が 近年論じられている（Lin \& Kunnathur, 2019; Yu, Nguyen, $\&$ Chen, 2016)。

さらに小野氏は「@Remote から取得できるデー夕を 見るようになってから，同じ紙詰まりでも，発生した時 間帯によってお客様の紙詰まりに対する感情が異なって いるのではないかと考えるようになった」と言う。「日中 であってもお客様は，紙詰まりに対して業務停止による
損害を感じると思うが, 残業中や遅い時間に紙詰まりが 発生した場合は，更に強く損害を感じていると考えるよ うになった」と説明してくれた。このように顧客の複合 機利用に関する詳細なデー夕を活用することで, 顧客の 機微を理解し, より深い顧客の理解を効率的に行うこと ができるようになると考えられる。顧客志向に焦点をあ て IoT の仕組みによって取得できるデー夕を利用した点 が成功要因の 1 つであるといえよう。

また，AI スマートッールによって自動生成される提案 書と確認資料も，顧客の立場に立って作成されていると 考えられる。例えば，印刷枚数の増減は顧客企業として は気になる点である。しかし, 印刷枚数の増減を顧客企 業が逐一確認をしているわけではない。また, 複合機の 使用頻度も，顧客企業は感覚的にどの程度使用している かを把握していたとしても，同機種の複合機を利用して いる他の企業と比較することはできない。これらのよう な顧客にとって知りたい情報が提案書に記載されている ことで，顧客は複合機の利用について理解を深めること ができる。また営業担当者にとっても, 顧客の使用状況 をあらかじめ理解した上で提案を行うことが可能となっ た。この点について小野氏も「提案書と確認資料の存在 が顧客満足に与える影響は大きい。もちろん顧客自身が 利用状況を把握できるという点もある。しかしそれ以上 に, 提案書と確認資料によって, 顧客の複合機使用状況 を理解したうえで営業担当者が顧客と話ができるように なったことが重要である。と述べている。提案書や確認 資料の例が示すように，顧客の立場に立った提案を行う ことができるような仕組みを作り，実践することによっ て，顧客企業の立場に立った提案が可能となっている。 その結果, 顧客企業はリコーに対するロイヤルティを形 成し，継続的な利用意向を高めていると考えらえる。

成功要因の 2 点目として, @Remoteによって取得さ れるデータのマーケティング戦略活用に際し, 営業担当 者の意見が非常に強く反映されている点が挙げられる。 中でも, 営業担当者の意見が反映される過程で, 営業担 当者の知識が共有されたことは注目すべき点である。営 業担当者の知識やノウハウの多くは一人ひとりの営業担 当者に蓄積されていた。今までは, 知識やノウハウが属 人化されていたため, いかに有効な知識であったとして 
も全社的に活用されてこなかった。しかし，@Remote によって取得できるデー夕を活用する際に，個々の営業 担当者に紐づいていた知識やノウハウも多く取り入れら れたのである。これによって，今まで多くの営業担当者 が気づかなかった顧客層や，顧客のインサイトに気づく ことになった。

小野氏は予測モデル変数の作成や改良に当たって，想 定もしない顧客の存在があることを，ある営業所の所長 から教わったという。故障や不良が発生していないにも かかわらず，リース契約期間が満了するよりも，かなり 前に買い替えを行う顧客層があるというのである。これ らの顧客はリース期限の終了を待たずして新たに発売さ れた製品へ買い替えを行うというのだ。この顧客層には 新製品が発売されたタイミングで買い替えを提案した場 合，買い替えの成約率が極めて高いであろう。このよう なことから，新製品の発売という変数が予測モデルに組 み込まれ，新製品が発売されると同時に，この層を担当 する営業担当者に，買い替え予測通知がメールで届くよ うにしたという。このように, @Remoteのデー夕を活 かす際に，営業担当者の知識が共有化された。これまで 勘と経験に基づいていた主観的な知識が，客観的なデー 夕を活用するにあたり，有効活用されるようになったと 考えられる。

さらに，営業担当者の意見の反映は，提案書と確認資 料の面でも見ることができる。上述の通り，マーケティ ングアナリティクスチームが提案書と確認資料の作成を 始めた際から，仕様や揭載すべき情報について営業担当

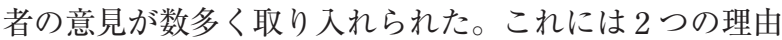
があると考えられる。1 点目は, 提案書や確認資料が営 業担当者にとって使いやすいッールにするためである。 提案書と確認資料は顧客別にカスタマイズされており, 顧客に最適な利用方法を提案することが可能なッールと なっている。実際に顧客企業を前にして提案を行う営業 担当者が，このッールを最大限活用できる為に彼らの意 見を多く採用したと考えられる。2 点目は，顧客企業に 伝えるべきデー夕を把握しているのが営業担当者である からである。@Remote から得られるデー夕の種類は非 常に多い。その中から, 顧客企業に対して伝えるべきデー 夕について最もよく理解しているのは，営業担当者に他
ならない。営業担当者は, 顧客とデー夕をつなぐ架け橋 としての役割を持っているため, 営業担当者の意見が数 多く採用されたと考えられる。

\section{VIII．結び}

本ケースでは, リコーの複合機利用データ収集ツール である@Remoteを活用した，既存顧客維持活動に着目 し、データを活用した効率的な顧客維持活動を検討した。 IoTを用いたデー夕活用を行うことで，効果的なタイミ ングで既存顧客のもとを訪問できるようになった。また, データを活用して既存顧客に最適な提案を行うことに よって，企業と顧客との間により媣い関係を築くことが できるようになった。

デー夕を活用したマーケティング事例は数多くあり， それ自体が珍しいわけではない。しかし，リコーの場合 は，@Remote から得られるデー夕の利用において，顧 客と接点の多い営業担当者の意見を多く採用している。 この点が，本ケースの特筆すべき点であると考元られる。 そして，彼らの意見を採用することで $2 つ の$ 利点が発生 した。1つは，営業担当者の知識が共有化された点であ る。属人化されていた知識が全社的に共有されたことは， 大きなメリットといえるだろう。 $2 つ$ 目は，営業担当者 の意見が顧客とデー夕の架け橋となっている点である。 データから顧客がとる行動のすべてを想像することは難 しい。また, データが豊富になるにつれて必要以上のデー 夕が取得され，マーケティング活動にとって重要なデー 夕が何であるかが判然としなくなることもある。これら の問題点に対して，データと顧客とをつなぐ営業担当者 の意見をデー夕活用に採用したという点は大きい。営業 担当者は，顧客の行動や意見に耳を傾けながら最適な提 案を行う。つまり，営業担当者は顧客の行動を知ったう えで, 顧客が求める情報をデー夕部門に伝えられる存在 であるといえよう。つまり, 営業担当者がデー夕と顧客 をつなぐ架け橋の役割となったことで，有効かつ最適な デー夕活用ができるようになったと考えられる。

今後，IoT デー夕を活用したマーケティング事例は， 現在以上に増えることは想像に難くない。しかし，デー 
Marketing Case マーケティングケースー シリーズ 137

夕を活用する際に顧客とデー夕を結ぶ存在となる営業担 当者が介在することで，顧客にとってだけではなく，企 業にとってもより有益なデー夕活用ができるようになる ことが本事例からうかがえる。今後の IoT デー夕活用に おける 1 つの方向性を考えるうえで，@Remoteによっ て蓄積されたデータのマーケティング活用という本ケー スは多くの示唆を与えてくれるであろう。

\section{謝辞}

本ケースの執筆にあたっては，株式会社リコー販売本 部マーケティングアナリティクステーマ小野裕明様, 福 住敦様にインタビューにご協力をいただきました。ここ に記して厚く感謝申し上げます。

注

1） Internet of Things の略。2012 年の ITU 報告書では，「既存 のもしくは革新的な相互運用可能な情報と通信技術によっ て物理的・仮想的なモノを相互に接続して高度なサービス の提供を可能にするための, 情報化社会におけるグローバ ルな基盤である」と定義している。（訳は Arai, 2018）

2）原稿と感光紙を密着させて赤外線を当てることによって行 われる印刷手法。原稿の文字部分が感光紙のジアゾ化合物 と化学反応することで印字される。

3) Research and Statistics Department Minister's Secretariat Ministry of International Trade and Industry（1983）による と, 1982 年の静電式複写機出荷台数は $1,374,670$ 台である。

4) Ricoh (2018) より。

5) IDC's Worldwide Quarterly Hardcopy Peripherals Tracker 2019Q2（2019）ょり。

6）リコーのデータ取得技術の歴史はさらに古く, 1994 年より ファックス回線を用いたデータ取得が行われており（Noda, 2009), 複合機での印刷枚数 (カウンター料金) データを取 得していた。

\section{References}

Arai, H. (2018). IoT (mono no internet) to energy management. IEEE Journal, 138(2), 90-93. (新井浩志 (2018)。「IoT（モ ノのインターネット) とエネルギーマネジメント」『電気学 会誌』138(2), 90-93) (In Japanese)

IDC (2019). IDC's Worldwide Quarterly Hardcopy Peripherals Tracker 2019Q2.

Kuriki, K. (2012). Radical and philosophical thought of marketing concept. Tokyo: Yuhikaku. (栗木契 (2012).『マーケティン グ・コンセプトを問い直す：状況の思考による顧客志向』 有斐閣）(In Japanese)

Lin, C., \& Kunnathur, A. (2019). Strategic orientations, developmental culture, and big data capability. Journal of Business Research, 105, 49-60.
Noda, R. (2009). “@Remote”: A new remote service for networked output devices and its system development. Journal of the Japan Society for Precision Engineering, 75(4), 475-478.（野田 怜子 (2009). 「出力機器のリモート管理サービス“@Remote” とそのシステム開発」『精密工学会誌』75(4), 475-478) (In Japanese)

Research and Statistics Department Minister's Secretariat Ministry of International Trade and Industry. (1983). Yearbook of machinery statistics. Tokyo: Tsusyou sangyou chousakai. (通 商産業大臣官房調査統計部編 (1983)。『昭和 57 年機械統計 年報』通商産業調查会) (In Japanese)

Ricoh Inc. (2018). 2018 nen 3 gatsu ki kessan no oshirase. Ricoh Inc. Retrieved from https://jp.ricoh.com/-/Media/Ricoh/Sites/ jp ricoh/IR/financial results/h30 3/pdf/flash report.pdf (September 10,2019)（株式会社リコー（2018）。「2018 年 3 月期決算の打知らせ」『株式会社リコー』）(In Japanese)

Yu, X., Nguyen, B., \& Chen, Y. (2016). Internet of things capability and alliance: Entrepreneurial orientation, market orientation and product and process innovation. Internet Research, 26(2), 402-434.

\section{河股 久司（かわまた ひさし）}

早稲田大学商学部卒業, 2018 年早稲田大学大学院商学研究 科修了。現在, 早稲田大学大学院商学研究科博士後期課程 に在籍。

\section{守口 剛（もりぐち たけし）}

早稲田大学政治経済学部卒業, 東京工業大学理工学研究科 経営工学専攻博士課程修了, 博士 (工学)。立教大学を経 て, 2005 年より現職。 